Agro-Science Journal of Tropical Agriculture, Food, Environment and Extension Volume 13 Number 3 September 2014 no. 37 - 48

ISSN III9-7455

\title{
RESPONSES OF MACROPROPAGATED MUSA PLANTLETS TO TRANSIENT MOISTURE STRESS IN SIX NURSERY SUBSTRATES
}

\author{
Baiyeri* K.P. and Aba S.C. \\ Department of Crop Science, University of Nigeria, Nsukka, Nigeria. \\ *Corresponding author: paul.baiyeri@unn.edu.ng ; Tel: +234-8039281834 \\ Formerly a visiting scientist to the International Institute of Tropical Agriculture, P.M.B 5320, Ibadan, \\ Oyo State, Nigeria
}

\begin{abstract}
Moisture stress causes serious devastating effects on crops ranging from retarded growth, tissue desiccation, and severe yield drop to outright death. In this study, the efficacy of six nursery substrates formulated in varying volume ratios of composted plantain fruit/bunch wastes (PFW), sawdust (SD), poultry manure (PM) and topsoil (TS) were evaluated on growth and moisture stress tolerance of macropropagated banana plantlets in the nursery. Un-amended topsoil was evaluated alongside five other substrates including PFW:SD (3:3), PFW:SD:PM (2:2:2), PFW:SD:PM:TS (11/2:11/2:11/2:11/2), SD:PM (3:3) and TS:PM (3:3) in a $6 \times 2$ factorial in completely randomized design (CRD) of ten replications. Two uniform sets of 10-week-old plants were used in the study. Watering was withdrawn on one set for 2 weeks, while the other set (watered daily throughout the study period) served as the control. The 2-week moisture stress was followed by a 4-week rehydration period, and thereafter, a second cycle water stress was induced for 3 weeks after which the plants were sampled for growth and dry matter accumulation. Results showed significant $(p<0.05)$ variability in plant growth and dry matter yield (DMY) across the nursery substrates, vis-à-vis the induced moisture stress. Plant growth and DMY were superior in PFW:SD:PM and PFW:SD:PM:TS, and were comparably good in most other media that contained $P M$ and or PFW. The deleterious effects of the induced moisture stress were most severe in plants raised in unamended topsoil. In addition to poor growth and reduced DMY observed in the stressed plants, these plants allotted a greater proportion of the accumulated dry matter to the underground components. It was evident from the study that inclusion of composted organic materials in nursery substrates supports the efficient utilization of available water by the plants. The use of organic substrates therefore holds promise for moisture stress management in nurseries. Irrigation (interval or volume) could be regulated to save labour, cut cost and optimize crop water use.
\end{abstract}

Keywords: Nursery media, sucker plantlets, water stress, banana.

\section{INTRODUCTION}

Plantain and banana (Musa species) are important food crops in the humid forest and mid-altitudes of subSaharan Africa. They provide more than $25 \%$ of the carbohydrate need of over 70 million people in the region (Ortiz and Vuylsteke, 1996). The productivity of Musa crops in West and Central Africa has, in the past four decades, suffered limitations posed by virulent black sigatoka leaf spot disease (caused by Mycosphaerella fijiensis Morelet), banana corm weevil (Cosmopolites sordidus Germar), and plant parasitic nematodes including Radopholus similis
(Cobb) Thorne, Pratylenchus spp., and Helicotylenchus multicinctus (Cobb); these biotic stresses spurred genetic improvement efforts in banana and plantains at the International Institute of Tropical Agriculture, Nigeria (Vuylsteke et al., 1993).

Since the inception of Plantain and Banana Improvement Programme (PBIP) of the International Institute of Tropical Agriculture (IITA) in 1987 at Onne station, Rivers State, breeders in search of hybrid seeds had continued to process large volumes of harvested fruits on-station. Volumes of senesced fruit 
Responses of Macro Propagated Musa Plantlets to Transient Moisture stress

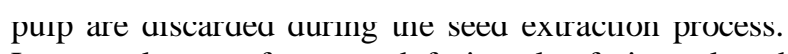
Large volumes of senesced fruit pulp, fruit peel and bunch wastes (peduncle tissues and fruit pedicel) from the postharvest processing of harvested fruits were often dumped as landfill in borrow pits on-station. When food wastes are not properly managed, they could constitute great environmental problems such as generation of odour, vermin attraction, toxic gas emission, groundwater contamination, and health hazard (Okareh et al., 2012).

At IITA, improved Musa clones are multiplied for dissemination to farmers through micro- and/or macropropagation techniques (Vuylsteke, 1998; Faturoti et al., 2002). Incidentally, the generated plantlets are first stabilized in the nursery before dissemination to the intending farmers (Baiyeri and Aba, 2007). Consequently, several organic nursery substrates have been developed for raising Musa plantlets to vigorous suckers for field planting (Baiyeri and Aba, 2005; Baiyeri and Aba, 2007). Considering the large volumes of topsoil used in commercial nurseries, and the eminent environmental threat posed by digging and carting of agricultural soils, it becomes necessary to develop soilless nursery substrates which in most cases possess better attributes and support seedling growth more than the conventional soil-based media (Akanbi et al., 2002; Baiyeri and Mbah, 2006).

Researchers (Baiyeri, 2000; Adeniji et al., 2007; Baiyeri et al., 2011; Makanjuola et al., 2013) have reported the preponderance of useful nutrients in plantain fruits; the peel is particularly rich in potassium, which together with nitrogen is needed in relatively large amounts by bananas. Although the use of plantain peel in biogas production and soap making (Ogazi, 1998), and in livestock feed formulation (Ogunsipe and Agbede, 2010) has been reported, there is need to further explore the utilization potential of plantain fruit/bunch wastes in crop-based systems considering the substantial nutrient content of plantains reported in literatures. Akanbi et al. (2002) reported the utilization of crop residue compost in nursery media formulations for fruit tree seedlings.

In an earlier study (Baiyeri and Aba, 2013), plantain waste compost and other organic materials were utilized in the formulation of nursery media for weaning Musa plantlets. Varying volume ratios of composted plantain fruit/bunch wastes (PFW), sawdust (SD), poultry manure (PM) and topsoil (TS) were evaluated on the growth and dry matter yield of excised banana plantlets.

In the present study, 10-week-old macropropagated banana plantlets raised in six nursery substrates [including PFW:SD (3:3), PFW:SD:PM

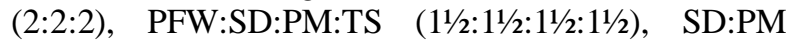
(3:3), TS:PM (3:3) and un-amended topsoil medium] were exposed to transient moisture stress to assess the giuwul respuises anu muisture stress tolerance of the banana plantlets across the six substrates. Water management is of prime importance in any successful nursery business (Bunt, 1988); and the quality of the nursery media determines to a large extent, the irrigation efficiency and effectiveness in containerized plants (Baiyeri and Mbah, 2006).

\section{MATERIALS AND METHODS Site description}

A pot experiment was conducted at the screen-house of the high rainfall station of the International Institute of Tropical Agriculture (IITA) at Onne $\left(4.43^{\circ} \mathrm{N}, 7.01^{\circ} \mathrm{E}\right.$, $10 \mathrm{~m}$ above sea level), Rivers State, southeast Nigeria between September, 2007 and March, 2008. The station is characterized by mean daily temperature of $27^{\circ} \mathrm{C}$, a unimodal annual rainfall of $2400 \mathrm{~mm}$ (which extends from early March through November each year), solar radiation averaging $14 \mathrm{MJm}^{-2}$ and high relative humidity ranging from $78-89 \%$ (Ortiz et al., 1997). A composite topsoil sample from the study location which was used for the study was characterized as sandy loam $(75 \%$ sand, $5 \%$ silt and $20 \%$ clay), and moderately acidic with a $\mathrm{pH}$ value of 5.7 .

\section{Design of the experiment}

In this study, macropropagated plantlets of 'Pisang lilin', a diploid landrace dessert banana (Musa spp. AA) were raised in six nursery substrates formulated in varying volume ratios of composted plantain fruit/bunch waste (PFW), sawdust (SD), poultry manure (PM), and or topsoil (TS). Un-amended topsoil medium was evaluated alongside five other media including PFW:SD (3:3), PFW:SD:PM (2:2:2), PFW:SD:PM:TS (11/2:11/2:11/2:11/2), SD:PM (3:3) and TS:PM (3:3) for growth and dry matter yield of banana plantlets under moisture stressed and controlled (nonstressed) conditions in $6 \times 2$ factorial experiment laidout in completely randomized design (CRD) of ten replications. Factor A represents the six nursery substrates as described above, while factor B represents two moisture regimes (moisture stressed and the normal non-stressed control conditions).

\section{Treatment application}

Ten plantlets each generated from humidity chamber (as earlier described in Baiyeri and Aba, 2007) were grown across the six nursery substrates in 3-litre plastic pots for a growth period of 5 months. The plantlets were uniformly watered twice every week for 10 weeks after planting. After full stabilization at 10 weeks, the plants were sorted into two uniform sets across the six nursery substrates. Watering was withdrawn on one set for 2 weeks, whereas the other set which served as the control plants were being watered twice weekly. After 
thi

Baiyeri K.P. and Aba S.C.

rehydrated (by routine watering twice per week) tor 4 weeks. Thereafter a second-cycle water stress was induced on same plants for 3 weeks, after which the two sets of plants (control and the moisture stressed plants) were sampled for growth and dry matter accumulation.

\section{Other nursery practices}

The plantain fruit/bunch wastes (senesced pulp, peel, peduncle and pedicel tissues) were chopped and cured (by sun drying) before used for the nursery media formulation. The nursery media formulations were thereafter composted in heaps under tarpaulin cover for 8 weeks before use. The substrates were moistened and turned for aeration fortnightly throughout the composting period. On the eve of the plantlet excision, the plantlets were cut-back to a uniform height of 15 $\mathrm{cm}$ while still attached to the mother corms in the propagation chamber. This helped to minimize transplanting shock and maintain fairly uniform plantlets used for the study.

\section{Data collection and analysis}

Plant growth variables were studied before and after the stress periods. Data were collected on number of live leaves and total emerged leaves (fully unfurled leaves) per plant, plant height $(\mathrm{cm})$, pseudostem base diameter $(\mathrm{cm}$ ), plant vigour (which was assessed using the score chart shown in Table 1), leaf retention index (\%) and total leaf area $\left(\mathrm{cm}^{2}\right)$ per plant. Leaf retention index was calculated for each plant as the ratio of live leaves maintained per plant to the total number of emerged leaves multiplied by 100 . Plant height was measured from the plant base (substrate level) to the Vjunction of the topmost opposite petioles, whereas pseudostem base diameter was taken at the plant base using a vernier calliper. The total leaf area per plant (length $\times$ widest width $\times 0.8$ ) was calculated for all the live leaves following Obiefuna and Ndubizu (1979). The plants were subjected to destructive sampling at the end of the study to assess the dry matter yield partitioned to the above-ground and below-ground components. Physicochemical properties of the substrates were also studied. The data were analyzed following the two-way procedure for factorial experiments in completely randomized design (CRD) using GenStat Release 10.3 DE (2011). The treatment means and the interaction effects were separated with st Significant Difference (F-LSD) at 5\% probability level for all traits whose F-test were found significant. The data collected at the end of the study were further subjected to principal component analysis (PCA) to identify the parameters that were most influenced by the nursery media and the moisture stress.

\section{RESULTS}

Results of the physicochemical analyses of the substrates (Table 2) show that the soilless nursery media (SD:PM, PFW:SD and PFW:SD:PM) were less dense and light-weighted compared to the soil-based substrates. The un-amended topsoil medium was particularly weighty; it recorded the highest value for bulk density followed by TS:PM medium. Porosity and water holding capacity values were also very much higher in the soilless substrates. Apart from the topsoil medium which recorded a moderately acidic $\mathrm{pH}$ of 5.7, all the other nursery substrates had slightly acidic to neutral $\mathrm{pH}$ ranging from 6.5 to 7.2. The organic matter content of the nursery substrate formulations ranged from 2.27 to $4.42 \%$, whereas the un-amended topsoil medium recorded the least value of $1.62 \%$. Apart from sodium and iron which were higher in the topsoil medium, the media formulations recorded a preponderance of essential plant nutrients. The nitrogen, phosphorus, potassium and magnesium contents of the topsoil medium were particularly low. Potassium contents of the nursery substrate formulations were comparably higher in the three nursery media where composted plantain fruit/bunch wastes were incorporated.

The data presented in Table 3 are the growth parameters of 12-week-old banana plants recorded after 2 weeks induced moisture stress. Growth parameters were generally superior in the normal nonstressed plants across the nursery substrates. Plant height and vigour were less influenced by the transient moisture stress and the media interaction effect. However, the cumulative increments in plant height and the number of live leaves per plant (measured as cumulative difference with reference to the base data collected prior to the two weeks moisture stress) were statistically $(\mathrm{p} \leq 0.05)$ higher in the media formulations compared to the un-amended topsoil medium; and were also higher in the non-stressed plants compared to the stressed plants. 


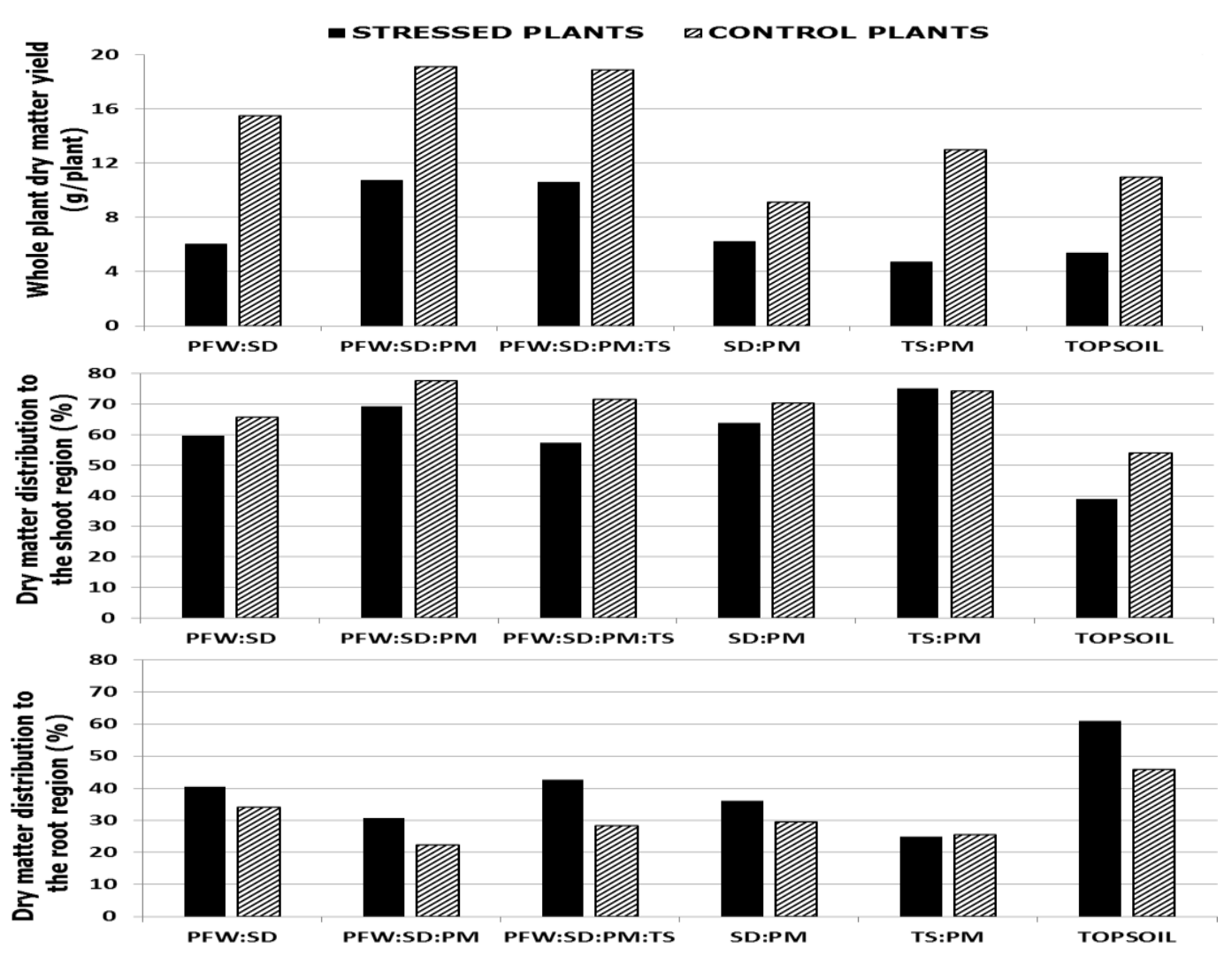

Figure 1: Dry matter yield and the partitioning pattern in water stressed and non-stressed (control) 19-week-old banana plants raised in six nursery substrates. $\mathrm{PFW}=$ Plantain fruit waste; SD $=$ Sawdust; $\mathbf{P M}=$ Poultry manure; TS = Topsoil.

Table 1: Vigour score chart used in the study for monitoring the growth of banana plantlets in the nursery.

\begin{tabular}{|c|l|}
\hline Vigour score & Description of growth indices \\
\hline 4 & Stout girth, vigorous and deep green \\
3 & Slender girth, moderate growth and greenish \\
2 & Moderate growth, pale green or chlorotic \\
1 & Retarded growth and generally poor performance \\
0 & Dead plant \\
\hline
\end{tabular}

The effects of the 2 weeks moisture stress were felt mostly on the leaf canopy parameters. Number of live leaves sustained per plant, total number of emerged leaves, and leaf retention index were statistically $(\mathrm{p} \leq$ 0.05 ) higher in the non-stressed plants. Conversely, the stressed plants recorded higher number of dry leaves, particularly in the un-amended topsoil medium. Interestingly, plants grown in PFW:SD:PM were able to sustain $100 \%$ of the photo-active leaves and also produced one additional leaf during the 2 weeks moisture stress period. The negative values observed in the cumulative growth change were due to desiccation and loss of tissues following the induced moisture stress. Data presented in Table 4 are growth parameters collected on 16-week-old banana plants after a four weeks rehydration period following an earlier 2-week moisture stress. Except for leaf retention index (LRI) and cumulative change in plant height, most of the parameters were not significantly influenced by media $x$ moisture stress interaction effect. Significant differences $(p \leq 0.05)$ in LRI between the non-stressed and the stressed plants were only recorded in the soilbased media (un-amended topsoil and TS:PM).

Notwithstanding the induced moisture stress, all the soilless media maintained similar level of leaf retention on the stressed and non-stressed plants. The medium 
PFW:SD sustained $100 \%$ of the total emerged leaves throughout the moisture stress and rehydration periods. Significant $(\mathrm{p}<0.05)$ increment in plant height between the stressed and the non-stressed plants was only recorded in PFW:SD and the soil-based medium (TS:PM). Significant effects of the nursery media were recorded in all the studied growth parameters after the four weeks rehydration period. Plant growth parameters were superior in the soilless media, particularly in PFW:SD:PM and PFW:SD:PM:TS, followed closely by TS:PM. Data on plant vigour showed clearly that the most vigorous plants were those raised in PFW:SD:PM and PFW:SD:PM:TS, while the poorest plants came from the un-amended topsoil medium. Also the largest increment in plant height and pseudostem diameter were recorded in plants raised in PFW:SD:PM and PFW:SD:PM:TS. The negative values recorded in cumulative growth change on pseudostem diameter and number of live leaves among the plants raised in the soil-based media (TS:PM and un-amended topsoil medium) are indications of shrinkage and loss of plant tissues occasioned by the transient moisture stress. Data on the main effect of moisture stress shows that the non- stressed plants performed better than the moisture stressed plants in terms of pseudostem diameter and leaf canopy parameters, but the 2 weeks moisture stress did not significantly ( $\mathrm{p}>0.05$ ) affect the eventual height of the plants, LRI and plant vigour. Data shown in Table 5 are the growth parameters of 19-week-old banana plants as influenced by nursery media effect and a second cycle 3 weeks moisture stress. Nonsignificant $(\mathrm{p}>0.05)$ media $\times$ moisture stress interaction effects were recorded on the eventual plant height, pseudostem diameter and plant vigour. Significant $(\mathrm{p} \leq 0.05)$ interaction effects were however recorded on leaf canopy parameters (number of live leaves, leaf area per plant, total number of emerged leaves, LRI) and the cumulative growth increments in plant height, pseudostem diameter and number of additional leaves. The leaf canopy parameters differed significantly between the stressed and the non-stressed plants across the media except in SD:PM where the stressed and the non-stressed plants performed seemingly alike. In every other media, leaf parameters (number, area and LRI) were statistically superior in the non-stressed plants.

Table 2: Physicochemical properties of the topsoil medium and nursery substrates used for the study.

\begin{tabular}{|c|c|c|c|c|c|c|}
\hline \multirow[b]{2}{*}{ Properties } & \multirow[b]{2}{*}{$\begin{array}{l}\text { Topsoil } \\
\text { medium }\end{array}$} & \multicolumn{5}{|c|}{ Nursery substrates formulated in volume ratios } \\
\hline & & $\begin{array}{l}\text { TS:PM } \\
(3: 3)\end{array}$ & $\begin{array}{l}\text { SD:PM } \\
(3: 3)\end{array}$ & $\begin{array}{c}\text { PFW:SD } \\
(3: 3)\end{array}$ & $\begin{array}{c}\text { PFW:SD:PM } \\
(2: 2: 2)\end{array}$ & $\begin{array}{l}\text { PFW:SD:PM:TS } \\
\left(1 \frac{1}{2}: 1 \frac{1}{2}: 1 \frac{1}{2}: 1 \frac{1}{1} / 2\right)\end{array}$ \\
\hline \multicolumn{7}{|c|}{ Physical properties } \\
\hline Bulk density $\left(\mathrm{g} . \mathrm{cm}^{3}\right)$ & 1.48 & 1.35 & 0.76 & 0.20 & 0.70 & 1.02 \\
\hline Total porosity (\%) & 54.2 & 58.6 & 83.7 & 88.2 & 85.8 & 69.5 \\
\hline Water holding capacity $\left(\mathrm{g} \cdot \mathrm{g}^{-1}\right)$ & 0.37 & 0.43 & 1.11 & 3.36 & 1.23 & 0.68 \\
\hline \multicolumn{7}{|c|}{ Chemical properties } \\
\hline $\mathrm{pH}$ in water & 5.7 & 6.2 & 6.4 & 7.2 & 6.5 & 6.8 \\
\hline Organic matter $(\%)$ & 1.62 & 3.41 & 4.42 & 2.27 & 3.59 & 2.45 \\
\hline Total nitrogen (\%) & 0.092 & 0.28 & 0.56 & 0.96 & 0.66 & 0.29 \\
\hline Phosphorus (\%) & 0.014 & 0.39 & 0.91 & 0.11 & 0.62 & 0.28 \\
\hline Potassium (\%) & 0.003 & 0.76 & 0.23 & 1.22 & 1.08 & 1.44 \\
\hline Calcium (\%) & 0.015 & 0.01 & 0.006 & 0.007 & 0.012 & 0.009 \\
\hline Magnesium (\%) & 0.002 & 0.085 & 0.053 & 0.042 & 0.080 & 0.080 \\
\hline Sodium $\left(\mathrm{mg} \cdot \mathrm{kg}^{-1}\right)$ & 87.4 & 5.52 & 27.57 & 29.10 & 34.70 & 15.54 \\
\hline Manganese (mg.kg $\left.{ }^{-1}\right)$ & 12.0 & 2.34 & 17.77 & 2.35 & 1.55 & 1.57 \\
\hline $\operatorname{Iron}\left(\mathrm{mg} \cdot \mathrm{kg}^{-1}\right)$ & 250 & 17.44 & 15.74 & 19.50 & 19.46 & 17.69 \\
\hline Cupper (mg.kg $\left.{ }^{-1}\right)$ & 1.25 & 8.67 & 2.46 & 7.45 & 11.20 & 9.43 \\
\hline Zinc $\left(\mathrm{mg} \cdot \mathrm{kg}^{-1}\right)$ & 9.97 & 11.80 & 24.76 & 14.99 & 16.85 & 15.14 \\
\hline
\end{tabular}

PFW = Plantain fruit waste; $\mathrm{SD}=$ Sawdust $; \mathrm{PM}=$ Poultry manure; $\mathrm{TS}=$ Topsoil. 
Table 3: Growth parameters* of banana plantlets as influenced by nursery media and a 2-weeks moisture stress period. Nursery Media Moisture Regime

\begin{tabular}{|c|c|c|c|c|}
\hline $\begin{array}{l}\text { Plant } \\
\text { height } \\
(\mathrm{cm})\end{array}$ & $\begin{array}{c}\text { No. of live } \\
\text { leaves }\end{array}$ & $\begin{array}{c}\text { No. of } \\
\text { dry } \\
\text { leaves }\end{array}$ & $\begin{array}{c}\text { Total } \\
\text { emerged } \\
\text { leaves }\end{array}$ & $\begin{array}{l}\text { Leaf retention } \\
\text { index }(\%)\end{array}$ \\
\hline
\end{tabular}

(cm)

PFW:SD
PFW:SD:PM

PFW:SD:PM:TS

SD:PM

TS:PM

TOPSOIL

$\mathrm{LSD}_{(0.05)}$ for interaction effect

$\begin{array}{lcll}\text { STRESSED } & 25.7 & 3.7 & 0.7 \\ \text { NORMAL } & 30.0 & 5.3 & 1.0 \\ \text { STRESSED } & 32.7 & 6.3 & 0.0 \\ \text { NORMAL } & 36.2 & 6.3 & 0.3 \\ \text { STRESSED } & 33.8 & 6.5 & 1.5 \\ \text { NORMAL } & 30.9 & 6.6 & 0.4 \\ \text { STRESSED } & 20.6 & 4.5 & 1.8 \\ \text { NORMAL } & 23.0 & 6.0 & 0.3 \\ \text { STRESSED } & 21.8 & 4.3 & 1.3 \\ \text { NORMAL } & 29.5 & 6.3 & 0.0 \\ \text { STRESSED } & 21.3 & 2.5 & 3.0 \\ \text { NORMAL } & 24.1 & 5.5 & 1.5 \\ \text { nst } & \mathrm{ns} & 1.5 & 1.1\end{array}$

PFW:SD

PFW:SD:PM

PFW:SD:PM:TS

SD:PM

TS:PM

TOPSOIL

$\operatorname{LSD}_{(0.05)}$ comparing media

STRESSED PLANTS

NORMAL PLANTS

$\mathrm{LSD}_{(0.05)}$ comparing moisture regime

*Data were collected on 12-week-old plants following a 2-weeks moisture stress period.

\begin{tabular}{cccccccc}
\multicolumn{7}{c}{ Main effect of nursery media } \\
\hline 27.8 & 4.5 & 0.8 & 5.3 & 82.9 & 2.5 & 1.5 & 0.3 \\
34.4 & 6.3 & 0.2 & 6.5 & 97.9 & 3.8 & 3.4 & 1.0 \\
32.3 & 6.6 & 0.9 & 7.5 & 88.3 & 3.8 & 3.6 & 0.1 \\
21.8 & 5.3 & 1.0 & 6.3 & 84.7 & 2.8 & 2.3 & 0.0 \\
25.6 & 5.3 & 0.6 & 5.9 & 85.4 & 2.4 & 1.9 & -0.2 \\
22.7 & 4.0 & 2.3 & 6.3 & 62.8 & 1.7 & -0.3 & -1.2 \\
6.1 & 1.0 & 0.8 & 0.9 & 12.7 & 0.7 & 1.6 & 0.8 \\
& & & Effect of moisture stress & & & -0.4 \\
\hline 26.0 & 4.6 & 1.4 & 5.9 & 75.9 & 2.7 & 3.2 & 0.5 \\
28.9 & 6.0 & 0.6 & 6.6 & 91.5 & 2.9 & 0.9 & 0.5 \\
ns & 0.6 & 0.4 & 0.5 & 7.3 & ns
\end{tabular}

$\uparrow$ Cumulative growth was measured as cumulative difference in growth parameters with reference to the base data collected at 10 weeks after planting prior to the induced moisture stress; ns $=$ non-significant at $5 \%$ probability level.

$\mathrm{PFW}=$ Plantain fruit waste $; \mathrm{SD}=$ Sawdust $; \mathrm{PM}=$ Poultry manure $; \mathrm{TS}=$ Topsoil .

Significant $(p \leq 0.05)$ effects of media were observed in all the studied growth parameters. Growth performances were superior in PFW:SD:PM and PFW:SD:PM:TS after the 3 weeks second cycle water stress. Plant performance was similar in PFW:SD, SD:PM and TS:PM; and poorest in the un-amended topsoil medium. The 3 weeks transient moisture stress significantly $(\mathrm{p} \leq 0.05)$ influenced all the studied growth parameters. The non-stressed plants performed significantly better than the moisture stressed plants in all the studied parameters.

The bar charts presented in Figure 1 show the whole-plant dry matter yield and the distribution to the shoot and root regions in water stressed and the nonstressed 19-week-old banana plants raised in six nursery substrates. Whole-plant dry matter yield (WPDMY) was superior and similar in PFW:SD:PM and PFW:SD:PM:TS, followed by PFW:SD and
SD:PM. Interestingly, the dry matter yields recorded in the stressed plants in PFW:SD:PM and PFW:SD:PM:TS were comparable to that recorded in non-stressed plants grown in the soil-based media (TS:PM and the un-amended topsoil). Also the WPDMY accumulated by stressed plants in the unamended topsoil medium was somewhat greater than that of the stressed plants in TS:PM, but a greater proportion of the accumulated dry matter in the former went to the underground components.

Dry matter yields allotted to the shoot region were generally higher in the media formulations compared to the un-amended topsoil medium, but plants grown in topsoil partitioned greater proportion of the accumulated dry matter to the root region. Similarly, the stressed plants partitioned more dry matter yield to the root region, while the non-stressed plants allotted more to the shoot in most of the media. 
Table 4: Effect of nursery media and moisture stress on growth of 16-week-old banana plants after a four-week rehydration period following a previous 2 -weeks induced water stress.

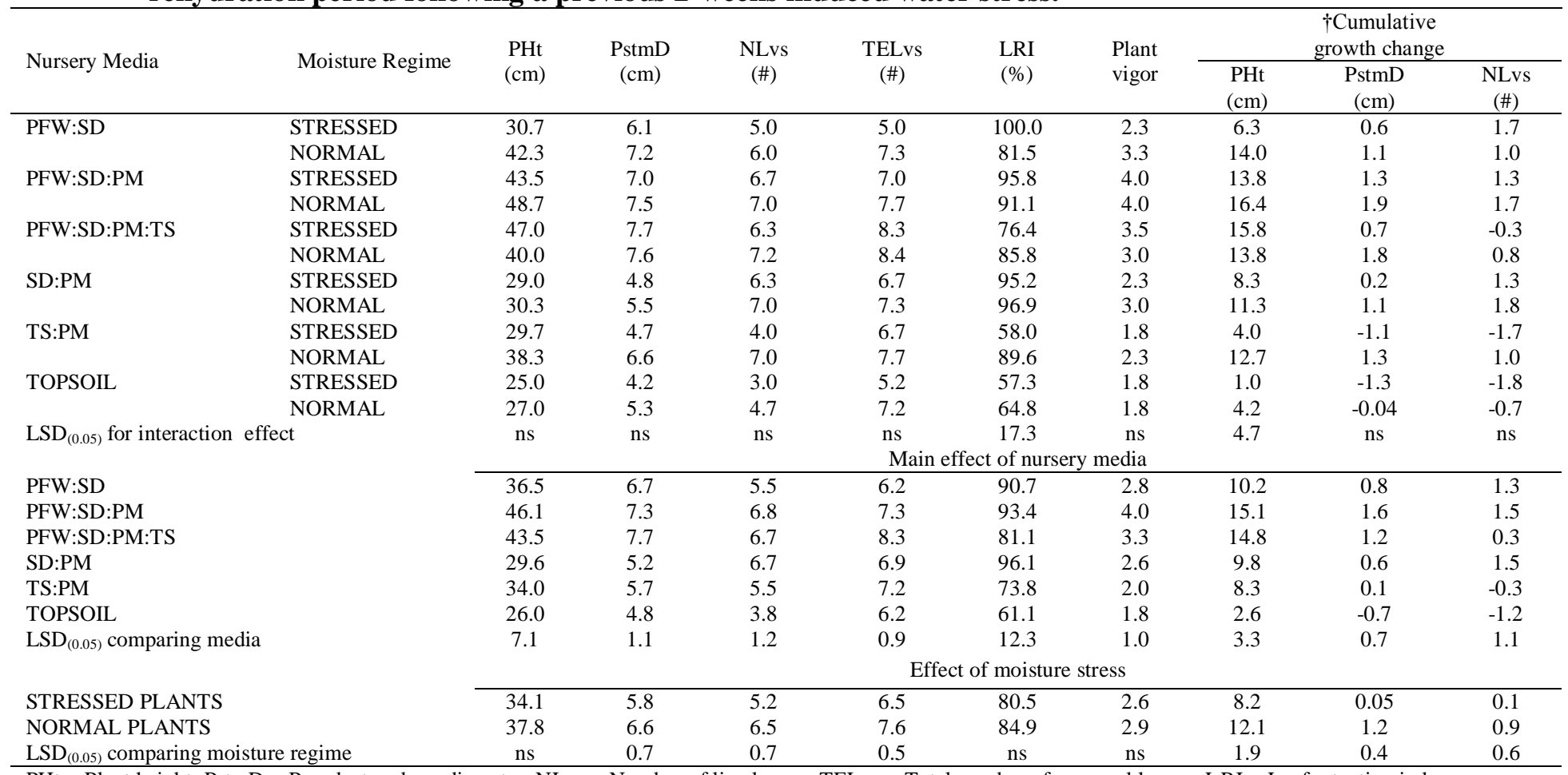

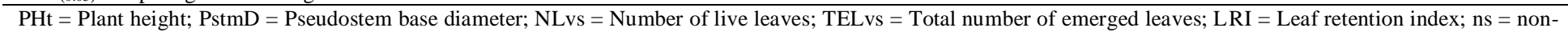

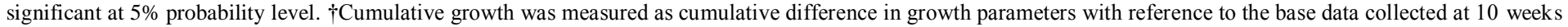
after planting prior to the induced moisture stress.

PFW = Plantain fruit waste; $\mathrm{SD}=$ Sawdust PM = Poultry manure; TS = Topsoil. 
Table 5: Effects of nursery media and induced moisture stress on growth parameters of banana plantlets. Data were collected on 19-week-old plants following a 3-weeks second cycle water stress.

\begin{tabular}{|c|c|c|c|c|c|c|c|c|c|c|c|c|c|}
\hline \multirow[t]{2}{*}{ Nursery Media } & \multirow[t]{2}{*}{$\begin{array}{l}\text { Moisture } \\
\text { Regime }\end{array}$} & \multirow[t]{2}{*}{ PHt (cm) } & \multirow[t]{2}{*}{$\begin{array}{l}\text { PstmD } \\
(\mathrm{cm})\end{array}$} & \multirow[t]{2}{*}{$\begin{array}{c}\text { NLvs } \\
(\#)\end{array}$} & \multirow[t]{2}{*}{$\begin{array}{c}\text { LA } \\
\left(\mathrm{cm}^{2}\right)\end{array}$} & \multirow[t]{2}{*}{$\begin{array}{c}\text { TELvs } \\
(\#)\end{array}$} & \multirow{2}{*}{\multicolumn{2}{|c|}{$\begin{array}{l}\text { LRI } \\
(\%)\end{array}$}} & \multirow[t]{2}{*}{$\begin{array}{l}\text { Plant } \\
\text { vigor }\end{array}$} & \multicolumn{4}{|c|}{$\begin{array}{l}\dagger \text { †umulative } \\
\text { growth change }\end{array}$} \\
\hline & & & & & & & & & & $\begin{array}{l}\mathrm{PHt} \\
(\mathrm{cm})\end{array}$ & $\begin{array}{l}\text { PstmD } \\
(\mathrm{cm})\end{array}$ & $\begin{array}{c}\text { NLvs } \\
(\#)\end{array}$ & \\
\hline \multirow[t]{2}{*}{ PFW:SD } & STRESSED & 30.0 & 4.9 & 4.0 & 526.0 & 5.7 & & & 2.7 & 5.7 & -0.6 & 0.7 & \\
\hline & NORMAL & 45.3 & 8.0 & 7.7 & 1903.0 & 9.0 & & & 3.0 & 17.0 & 1.8 & 2.7 & \\
\hline \multirow[t]{2}{*}{ PFW:SD:PM } & STRESSED & 45.2 & 7.0 & 4.0 & 989.0 & 8.7 & & & 3.0 & 15.5 & 1.3 & -1.3 & \\
\hline & NORMAL & 58.0 & 9.0 & 9.0 & 2771.0 & 10.3 & & & 4.0 & 25.7 & 3.3 & 3.7 & \\
\hline \multirow{2}{*}{$\begin{array}{l}\text { PFW:SD:PM: } \\
\text { TS }\end{array}$} & STRESSED & 44.5 & 6.7 & 2.8 & 795.0 & 8.5 & & & 2.8 & 13.3 & -0.3 & -3.8 & \\
\hline & NORMAL & 46.8 & 8.7 & 8.0 & 2362.0 & 10.2 & & & 3.4 & 20.6 & 2.8 & 1.6 & \\
\hline \multirow[t]{2}{*}{ SD:PM } & STRESSED & 30.8 & 5.9 & 6.0 & 989.0 & 7.7 & & & 2.3 & 10.2 & 1.2 & 1.0 & \\
\hline & NORMAL & 39.0 & 6.3 & 7.3 & 1315.0 & 8.8 & & & 2.8 & 20.0 & 1.9 & 2.0 & \\
\hline \multirow[t]{2}{*}{ TS:PM } & STRESSED & 32.3 & 4.7 & 2.5 & 510.0 & 7.5 & & & 1.0 & 5.8 & -0.8 & -3.5 & \\
\hline & NORMAL & 45.3 & 7.4 & 7.3 & 2006.0 & 9.3 & & & 2.3 & 19.7 & 2.1 & 1.3 & \\
\hline \multirow[t]{2}{*}{ TOPSOIL } & STRESSED & 24.4 & 3.5 & 1.4 & 192.0 & 5.2 & & & 0.8 & 0.4 & -2.0 & -3.4 & \\
\hline & NORMAL & 26.7 & 5.8 & 4.5 & 1036.0 & 7.7 & & & 1.8 & 3.8 & 0.5 & 0.8 & \\
\hline \multirow{2}{*}{\multicolumn{2}{|c|}{$\operatorname{LSD}_{(0.05)}$ for interaction effect }} & $\mathrm{ns}$ & $\mathrm{ns}$ & 1.4 & 916.0 & 1.0 & & & $\mathrm{~ns}$ & 5.9 & 1.2 & 1.9 & \\
\hline & & \multicolumn{12}{|c|}{ Main effect of nursery media } \\
\hline \multicolumn{2}{|l|}{ PFW:SD } & 37.7 & 6.4 & 5.8 & 1214.0 & 7 & & 77.2 & 2.8 & 11.3 & 0.6 & & 1.7 \\
\hline \multicolumn{2}{|l|}{ PFW:SD:PM } & 51.6 & 8.0 & 6.5 & 1880.0 & 9 & & 66.6 & 3.5 & 20.6 & 2.3 & & 1.2 \\
\hline \multicolumn{2}{|c|}{ PFW:SD:PM:TS } & 45.6 & 7.7 & 5.4 & 1579.0 & & & 55.5 & 3.1 & 16.9 & 1.2 & & -1.1 \\
\hline \multicolumn{2}{|l|}{ SD:PM } & 34.9 & 6.1 & 6.6 & 1152.0 & 8 & & 80.8 & 2.5 & 15.1 & 1.5 & & 1.5 \\
\hline \multicolumn{2}{|l|}{ TS:PM } & 38.8 & 6.1 & 4.9 & 1258.0 & & & 55.3 & 1.6 & 12.7 & 0.7 & & -1.1 \\
\hline \multicolumn{2}{|l|}{ TOPSOIL } & 25.5 & 4.7 & 3.0 & 614.0 & & & 49.0 & 1.3 & 2.1 & 0.8 & & -2.1 \\
\hline \multicolumn{2}{|c|}{$\mathrm{LSD}_{(0.05)}$ comparing media } & 7.7 & 1.2 & 1.0 & 648.0 & & & 16.1 & 0.7 & 4.2 & 0.8 & & 1.3 \\
\hline \multirow{2}{*}{\multicolumn{2}{|c|}{ STRESSED PLANTS }} & \multicolumn{12}{|c|}{ Effect of moisture stress } \\
\hline & & 34.5 & & 5.5 & 3.4 & $\begin{array}{r}667 . \\
0\end{array}$ & 2 & 49.6 & 2.1 & 8.5 & -0.2 & & -1.7 \\
\hline \multicolumn{2}{|c|}{ NORMAL PLANTS } & 43.5 & & 7.5 & 7.3 & $\begin{array}{r}189 \\
9.0\end{array}$ & $\begin{array}{l}9 . \\
2\end{array}$ & 78.6 & 2.9 & 17.8 & 2.1 & & 1.7 \\
\hline \multicolumn{2}{|c|}{$\begin{array}{l}\mathrm{LSD}_{(0.05)} \text { comparing moisture } \\
\text { regime }\end{array}$} & 4.5 & & 0.7 & 0.6 & 916.0 & $\begin{array}{l}0 . \\
4\end{array}$ & 9.3 & 0.4 & 2.4 & 0.5 & & 0.8 \\
\hline
\end{tabular}

PHt = Plant height PstmD = Pseudostem base diameter; NLvs = Number of live leaves; LA = Leaf area per plant; TELvs = Total number of emerged leaves; LRI = Leaf retention index; ns = non-significant at $5 \%$ probability level. $\dagger$ Cumulative growth was measured as cumulative difference in growth parameters with reference to the base data collected at 10 weeks after planting prior to the induced moisture stress.

$\mathrm{PFW}=$ Plantain fruit waste; $\mathrm{SD}=$ Sawdust $\mathrm{PM}=$ Poultry manure; $\mathrm{TS}=$ Topsoil. 
Table 6: 'Principal component analysis (PCA) showing the relative contributions (Eigen vector values) of the studied parameters to the total variability due to media and moisture stress treatments.

\begin{tabular}{|c|c|c|c|c|}
\hline \multirow[b]{2}{*}{ PLANT TRAITS } & \multicolumn{4}{|c|}{ Latent vector loadings } \\
\hline & Prin1 & Prin2 & Prin3 & Prin4 \\
\hline Corm dry matter $(\mathrm{g})$ & -0.16543 & -0.18954 & 0.64844 & 0.41418 \\
\hline Plant height $(\mathrm{cm})$ & -0.31492 & -0.15772 & -0.06406 & -0.39186 \\
\hline Total leaf area $\left(\mathrm{cm}^{2}\right)$ & -0.33231 & 0.06461 & -0.06670 & -0.03474 \\
\hline Leaf retention index $(\%)$ & -0.18761 & 0.54095 & 0.17953 & -0.02434 \\
\hline Leaf dry matter $(\mathrm{g})$ & -0.33509 & 0.03006 & -0.01708 & -0.02664 \\
\hline Number of dry leaves & 0.13193 & -0.56500 & -0.32859 & 0.11045 \\
\hline Number of live leaves & -0.28054 & 0.35409 & -0.16252 & 0.27992 \\
\hline Pseudostem dry matter (g) & -0.28879 & -0.26037 & 0.15661 & -0.43570 \\
\hline Root dry matter (g) & -0.25989 & -0.30504 & 0.10360 & 0.37868 \\
\hline Pseudostem diameter $(\mathrm{cm})$ & -0.32742 & -0.12336 & 0.00133 & -0.05965 \\
\hline Whole plant dry matter $(\mathrm{g})$ & -0.33005 & -0.13407 & 0.16892 & -0.02722 \\
\hline Total emerged leaves & -0.26043 & -0.00821 & -0.49332 & 0.46454 \\
\hline Plant vigour & -0.29075 & 0.05285 & -0.31130 & -0.16884 \\
\hline Latent Roots & 8.359 & 2.140 & 1.320 & 0.374 \\
\hline Percentage variation $(\%)$ & 64.30 & 16.46 & 10.15 & 2.88 \\
\hline
\end{tabular}

'PCA was performed on the data collected at the end of the study based on correlation matrix.

The principal component analysis result shown in Table 6 captured approximately $94 \%$ of the total variation that existed among the plants following the media and moisture stress treatments. Eight traits including plant height, leaf area per plant, leaf dry matter yield, number of live leaves, pseudostem dry matter yield, pseudostem diameter, whole plant dry matter yield, and plant vigour were the most varied traits contributing about $64 \%$ of the existed variability. These traits together with leaf retention index, number of dry leaves and corm dry matter yield contributed about $94 \%$ of the observed variability among the plants following the media and moisture stress treatments. Majority of the identified traits are aerial vegetative traits, indicating that the media and moisture stress treatments influenced more of the shoot growth parameters.

\section{DISCUSSION}

The discernable variability in growth performance and dry matter yield, and distribution among the test plants is attributable to the variations observed in the physicochemical properties of the nursery media, vis-àvis the effect of the transient moisture stress. Plant performances were superior and similar in the substrates - PFW:SD:PM and PFW:SD:PM:TS, followed closely by TS:PM and PFW:SD, and were poorest in the un-amended topsoil medium. This is suggestive that soils of the study location used in the study were poor in native fertility and physical attributes, and thus, could not support healthy plants without external nutrient amendment.

In a similar study (Baiyeri and Aba, 2013), the medium - PFW:SD:PM supported the best plant growth and was adjudged the best among the six nursery media developed for weaning Musa plantlets. An earlier study (Baiyeri, 2005) recommended a mixture of ricehull and poultry manure $(3: 1, \mathrm{v} / \mathrm{v})$ for raising Musa plantlets to plantable suckers. Studies on nursery media formulation had shown that the component base materials determine the physicochemical attributes of the nursery media (Wilson et al., 2001; Akanbi et al., 2002; Baiyeri and Mbah, 2006); which in turn determine the quality of the nursery seedlings (Baiyeri, 2005; Baiyeri and Aba, 2013).

In the present study, plant performances (in terms of growth, leaf canopy parameters and dry matter yield) were obviously better in the substrates where plantain waste compost and or poultry manure were incorporated. These substrates had slightly acidic to neutral $\mathrm{pH}$ of 6.5 to 7.2 , which is ideal for plant growth. Conversely, the un-amended topsoil medium recorded a moderately acidic $\mathrm{pH}$ of 5.7. Organic matter content was two to four-folds higher in the nursery substrate formulations than in the un-amended topsoil medium. Besides the supply of plant nutrients to the nursery plants, the organic amendments (plantain waste compost and poultry manure) imparted to the nursery substrates good physical attributes. 
The soilless media (SD:PM, PFW:SD, PFW:SD:PM) were less dense, with bulk density values ranging from 0.2 to 0.76 g. $\mathrm{cm}^{3}$, compared to values of 1.02 to 1.48 g. $\mathrm{cm}^{3}$ recorded in the soil-based media. Total porosity and water holding capacity were higher in the soilless media compared to the soil-based media (the topsoil medium, TS:PM, PFW:SD:PM:TS). The physical attributes of a nursery medium have profound implications on root aeration and drainage, as well as, nutrient and water uptake, and anchorage with consequent effect on the quality of the seedlings produced (Baiyeri, 2005).

Plantain fruits contain substantial amounts of bioavailable nutrients (Baiyeri et al., 2011; Makanjuola et al., 2013), and the peel is particularly rich in potassium (Ogazi, 1998; Baiyeri, 2000, Adeniji et al., 2007). Manure, especially of poultry, is also a good source of plant nutrients (Amanullah, 2007); and its application to agricultural soils often modulates the physicochemical properties of the soil and enhances plant growth (Brandjes et al., 1989). The nursery media - PFW:SD:PM and PFW:SD:PM:TS must have provided ideal conditions for plant growth, and supplied essential nutrients in the right proportion for optimum seedling growth.

Moisture availability has been identified as a critical productivity determining factor in Musa species (Robinson and Bower, 1986; Turner et al., 2007). Moisture deficit hampers physiological processes in plants, thereby imposing huge reductions in crop yield via diminished leaf carbon fixation and general growth inhibition (Chaves and Oliveira, 2004). In the present study, significant effects of the induced moisture stress were felt mostly on the leaf canopy parameters (number of live and dry leaves per plant, total leaf area per plant, leaf retention and total number of emerged leaves) with the consequent effect on shoot growth and dry matter accumulation. The effects of the moisture stress (like tissue desiccation, shrinkage, loss of leaf tissues, reduced dry matter yield, and redistribution of dry matter to the root region) were comparatively mild on plants raised in the soilless media, particularly those media that contained plantain waste compost. Plants raised in PFW:SD:PM and PFW:SD sustained 100\% of the total emerged leaves, and even produced additional leaf during the first cycle moisture stress. Even with the induced moisture stress, all the soilless media maintained similar level of leaf retention on the stressed and non-stressed plants. Also the dry matter yields recorded in the stressed plants in PFW:SD:PM and PFW:SD:PM:TS were similar to that recorded in non-stressed plants grown in the soil-based media (TS:PM and the topsoil medium). The water holding capacity and potassium contents of soilless media were comparatively higher than those of the soil-based media.
Of the mineral nutrients, potassium is reported the most valuable in combating the ill-effects of soil water stress (De Boer, 1999). Potassium influences the water economy and crop growth through its effects on water uptake, root growth, maintenance of turgor, transpiration and stomatal regulation (Mengel, 2007). It has an important role in major plant processes such as photosynthesis, respiration, protein synthesis and enzyme activation, water uptake, osmoregulation, general growth and yield of plants (Zaidi et al., 1994). The roles of organic matter in the soil are multifarious. It serves as reservoir of nitrogen and other nutrients required by plants. Other important functions include the formation of stable aggregates, maintenance of biological functions including the immobilization and release of nutrients, improvement of ion exchange capacity, and conservation of terrestrial carbon and soil water (Scholes et al., 1994). The role of organic matter in the formation of stable soil aggregates has major implications on soil structure formation and, therefore, on water infiltration, water holding capacity, aeration, soil strength and resistance to root growth (Carter, 2002).

Baiyeri and Mbah (2006) reported that nursery seedlings grown in soilless organic compost showed delayed manifestation of water stress symptoms owing to the high water holding capacity of such media. There is no doubt that the inclusion of plantain waste compost, poultry manure and sawdust as nursery media components in the present study provided ideal conditions for the growth of Musa plantlets (in terms of nutrient and water supply, and anchorage).

The nursery media - PFW:SD:PM and PFW:SD:PM:SL produced the healthiest plants and sustained the growth of Musa plantlets to plantable suckers, even with the two and three weeks moisture stress. These media have the capacity to conserve moisture for nursery grown plants. As such, irrigation (interval or volume) could be regulated by nurserymen to save labour, cut cost, and optimize crop water use. By the use of soilless organic compost in nursery or growth media preparations, agricultural soils would be better conserved. Moreover, a vast array of organic wastes emanating from farm produce, homes, markets, eateries, institutions, etc., would be recycled back to agriculture.

\section{ACKNOWLEDGEMENT}

The authors are grateful to the management and staff of the Plantain and Banana Improvement Programme (PBIP) of the International Institute of Tropical Agriculture (IITA), Onne, Rivers State, Nigeria for funding and allowing the use of IITA facilities for the conduct of this research. 
Baiyeri K.P. and Aba S.C.

\section{REFERENCES}

Adeniji TA, Sanni LO, Barimalaa IS, Hart AD (2007). Nutritional and anti-nutritional composition of flour made from plantain and banana hybrid pulp and peel mixture. Nigerian Food Journal, 25( 2): 68-76.

Akanbi BW, Togun AO, Baiyewu RA (2002). Suitability of plant residue compost as nursery medium for some tropical fruit tree seedlings. Moor Journal of Agricultural Research 3: 24-29.

Amanullah MM (2007). Nutrient release pattern during composting poultry manure. Research Journal of Agriculture and Biological Sciences, 3(4): 306-308.

Baiyeri KP (2000). Effect of nitrogen fertilization on mineral concentration in plantain Musa AAB) fruit peel and pulp at unripe and ripe stages. Plant Product Research Journals, 5: 38-43.

Baiyeri KP (2005). Response of Musa species to macro-propagation. II: The effects of genotype, initiation and weaning media on sucker growth and quality in the nursery. African Journal of Biotechnology, 4(3): 229-234

Baiyeri KP, Aba SC (2007). A review of protocols for macropropagation in Musa species. Fruit, Vegetable and Cereal Science and Biotechnology, 1(2): 110-115.

Baiyeri KP, Aba SC (2013) Physicochemical characteristics of nursery media formulated from organic wastes influenced growth and dry matter yield of banana (Musa AA var. Pisang lilin) plantlets. Nigerian Journal of Horticultural Science, 17:135-145.

Baiyeri KP, Aba SC, Otitoju GT, Mbah OB (2011). The effects of ripening and cooking method on mineral and proximate composition of plantain (Musa sp. AAB cv. 'Agbagba') fruit pulp. African Journal of Biotechnology, 10 (36): 6979-6984.

Baiyeri KP, Mbah BN (2006). Effects of soilless and soil-based nursery media on seedling emergence, growth and response to water stress of African breadfruit (Treculia Africana Decne ). African Journal of Biotechnology 5(15):1405-1410.

Brandjes P, Van Dongen P, Yan de Veer A (1989). Green manuring and other forms of soil improvement in the tropics. Agrodok
28, Agromisa Foundation Press, Wageningen, Netherlands.

Bunt AC (1988). Media and mixes for container grown plants. A manual on the preparation and use of growing media for pot plants (2nd Ed.), Uwing Hyman Ltd, London, $307 \mathrm{p}$.

Carter MR (2002). Soil quality for sustainable land management: organic matter and aggregation interactions that maintain soil functions. Agronomy Journal, 94: 38-47.

Chaves MM, Oliveira MM (2004). Mechanisms underlying plant resilience to water deficit: prospect for water-saving agriculture. Journal of Experimental Botany, 55: 2365-2384.

De Boer AH (1999). Potassium translocation into the root xylem. Plant Biology, 1(1): 3645.

Faturoti B, Tenkouano A, Lemchi J, Nnaji N (2002) Rapid multiplication of plantain and banana: Macropropagation techniques. A pictorial guide, IITA, Ibadan, Nigeria, $12 \mathrm{p}$.

GenStat Release 10.3 DE (2011). Discovery Edition 4, VSN International Ltd, Rothamsted Experimental Station, Hemel, Hempstead, UK.

Makanjuola OM, Ajayi AB, Kolawole M, Makanjuola JO (2013). The proximate composition and mineral contents of three plantain cultivars harvested at matured green level. International Journal of Innovations in Bio-Sciences $3(2): 23-26$.

Mengel K (2007). Potassium. Pp. 91-120 in: Handbook of Plant Nutrition. Barker AV, Pilbeam DJ (eds.), CRC Press, New York.

Obiefuna JC, Ndubizu TOC (1979). Estimating leaf area of plantain. Scientia Horticulturae 11: 31 - 36.

Ogazi PO (1998). Plantain storage and processing. Pp. 108-119 in: Postharvest Technology and Commodity Marketing. (Ferris RSB, ed.), Proceedings of a Postharvest Conference on Technology and Commodity Marketing in West Africa, 29 Nov. to 1 Dec., Accra, Ghana. Published by the International Institute of Tropical Agriculture (IITA) Ibadan, Nigeria.

Ogunsipe MH, Agbede JO (2010) The replacement value of unripe plantain 
peels on the growth performance, carcass characteristics and cost implications of rabbit production in the tropical region. Researcher, 2(11): $24-$ 29.

Okareh OT, Oyewole SA, Taiwo LB (2012). Conversion of food wastes to organic fertilizer: a strategy for promoting food security and institutional waste management in Nigeria. Journal of Research in Environmental Science and Toxicology, 1(2): 29-35.

Ortiz R, Austin PD, Vuylsteke D (1997). IITA high rainfall station: Twenty years of research for sustainable agriculture in the West African humid forest. HortScience, 32: 969 - 972.

Ortiz R, Vuylsteke D (1996). Improving plantain and banana based systems. Pp. 1-7 in: Plantain and Banana - production and research in west and central Africa. Ortiz, R and M. O. Akoroda (eds). Proc. of regional workshop, held at High Rainfall Station, Onne, Rivers State, Nigeria, 23-27 $7^{\text {th }}$ September, 1995. Published by the International Institute of Tropical Agriculture (IITA), Ibadan, Nigeria.

Robinson JC, Bower JP (1986). Transpiration characteristics of banana leaves (cultivar 'Williams') in response to progressive depletion of available soil moisture. Scientia Horticulturea, 30: 289-300.

Scholes RJ, Dalal R, Singer S (1994). Soil physics and fertility: The effects of water, temperature and texture. Pp. 117-136 in: The Biological Management of Soil Fertility. Woomer PL, Swift MJ (eds.), John Wiley and Sons, Chichester, West Sussex, England.
Turner DW, Fortescue JA, Thomas DS (2007). Environmental physiology of the bananas (Musa spp.). Brazilian Journal of Plant Physiology, 19(4): 463-484.

Vuylsteke D (1998) Shoot-tip culture for the propagation, conservation, and distribution of Musa germplasm. IITA, Ibadan, Nigeria, $73 \mathrm{p}$.

Vuylsteke D, Ortiz R, Pasberg-Gauhl C, Gauhl F, Gold C, Ferris S, Speijer P (1993) Plantain and Banana Research at the International Institute of Tropical Agriculture. HortScience, 28(9): 874, 970-971.

Wilson SB, Stoffella PJ, Graetz DA (2001). Use of compost as a media amendment for containerized production of two subtropical perennials. Journal of Environmental Horticulture, 19(1): 3742.

Zaidi PH, Khan FA, Chaturvedi GS (1994). Physiological role of potassium under stress environment. Fertilizers News, 39: 47-49. 